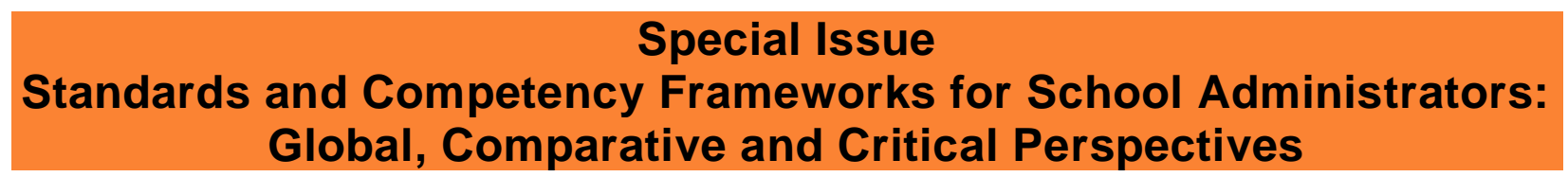

education policy analysis

\title{
archives
}

A peer-reviewed, independent, open access, multilingual journal

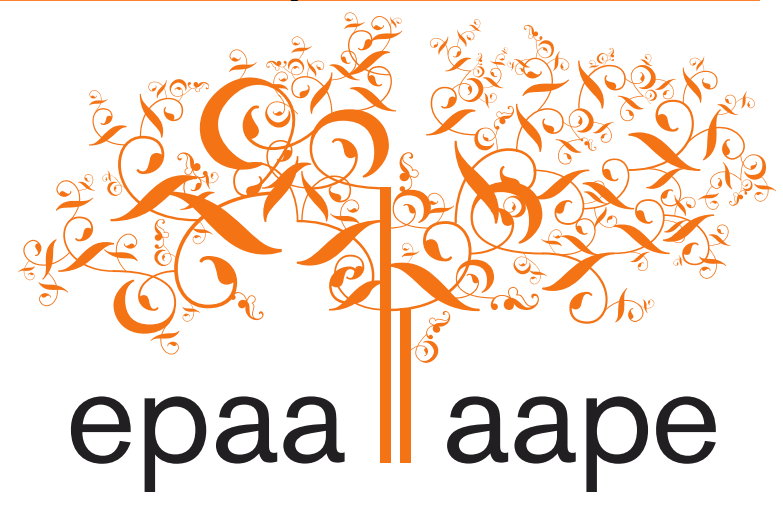

Arizona State University

Volume 27 Number $115 \quad$ September 23, 2019

ISSN 1068-2341

\section{Preparing School Leaders for America's Wicked Problems? How the Revised PSEL and NELP Standards Address Equity and Justice}

\author{
Amy N. Farley \\ University of Cincinnati \\ $\&$ \\ Joshua Childs \\ Olivia A. Johnson \\ University of Texas at Austin \\ United States
}

Citation: Farley, A.N., Childs, J., \& Johnson, O.A. (2019). Preparing leaders for wicked problems? How the revised PSEL and NELP standards address equity and justice. Education Policy Analysis Archives, 27(115). [EPAA will assign the DOI]. This article is part of a special issue, Standards and Competency Frameworks for School Administrators: Global, Comparative and Critical Perspectives, guest edited by Augusto Riveros and Wei Wei.

Abstract: The past 20 years have seen a shift in school leaders' work that can best be characterized by an increasing complexity in expectations and greater demands for accountabilities. Educational leadership preparation programs and professional associations responded to these shifts, in part, with the development and proliferation of standards for both pre-service (ELCC and NELP) and practicing (ISLLC and PSEL) educational leaders. Both sets of standards have undergone significant 
revision in the last five years, largely in response to shifts in the work required of school administrators in today's 21 st century schools. However, what remains an open empirical question is whether the leadership standards are robust and pragmatic enough to tackle the various educational issues that school leaders face. In other words, do various school leadership standards prepare and assess school administrators appropriately? Using the wicked problems framework, we examine the extent to which the revised PSEL and NELP standards capture the challenging work required for school leaders to act as inclusive leaders and "equity-oriented change agents" (Maxwell, Locke, \& Scheurich, 2013, p. 1). We utilize qualitative content analysis (Weber, 1990) to analyze the content of the leadership standards, focusing in particular on the ways those standards represent evolving conceptions of equity and justice. These analyses suggest that although both sets of standards have changed considerably from their predecessors, they may not go far enough to help leaders determine how to implement the proper administrative authority to solve complex issues. This is particularly true as it relates to the persistent, wicked equity problems facing our schools.

Keywords: Principal standards; wicked problems; leadership; equity; justice

\section{¿Preparando líderes para problemas wicked? Cómo las normas revisadas abordan la equidad y la justicia}

Resumen: En los últimos 20 años, el trabajo del trabajo de los líderes escolares ha aumentado la complejidad en las expectativas y las mayores demandas de responsabilidad. Los programas de preparación para el liderazgo educativo y las asociaciones profesionales respondieron a estos cambios, en parte, con el desarrollo y la proliferación de estándares para todo tipo de líderes educativos en las escuelas actuales del siglo XXI. ¿Pero estos estándares preparan y evalúan a los administradores escolares de manera apropiada? Utilizando el marco de los problemas wicked, examinamos hasta qué punto los estándares revisados capturan el trabajo desafiante requerido para que los líderes escolares actúen como inclusivos y orientados a la equidad. Analizamos el contenido de los estándares de liderazgo y nos enfocamos en las formas en que esos estándares representan concepciones cambiantes de equidad y justicia. Estos análisis sugieren que, aunque los estándares han cambiado, es posible que no lleguen lo suficientemente lejos como para ayudar a los líderes a resolver problemas complejos, en particular los problemas de equidad persistentes y wicked en las escuelas de hoy.

Palabras-clave: estándares; problemas wicked; liderazgo; equidad; justicia

\section{Preparando líderes para problemas wicked? Como os padrões revisados tratam da justiça e da justiça}

Resumo: Nos últimos 20 anos, o trabalho dos líderes das escolas aumentou a complexidade das expectativas e as demandas por responsabilidades. Os programas de preparação para a liderança educacional e associações profissionais responderam a essas mudanças, em parte, com o desenvolvimento e a proliferação de padrões para todos os tipos de líderes educacionais nas escolas de hoje no século XXI. Mas esses padrões preparam e avaliam os administradores da escola adequadamente? Usando a estrutura de problemas wicked, examinamos até que ponto os padrões revisados capturam o trabalho desafiador necessário para os líderes das escolas agirem de maneira inclusiva e orientada para a equidade. Analisamos o conteúdo dos padrões de liderança e focamos nas maneiras pelas quais esses padrões representam concepções em mudança de justiça e justiça. Essas análises sugerem que, embora os padrões tenham mudado, eles podem não ir longe o suficiente para ajudar os líderes a resolver problemas complexos, particularmente 
problemas persistentes e wicked de equidade nas escolas de hoje.

Palavras-chave: padrões; problemas wicked; liderança; equidade; justiça

\section{Preparing Leaders for Wicked Problems? How the Revised Educational Leadership Standards Address Equity and Justice}

Over the past 20 years, policymakers have increased expectations and demands for accountability in U.S. school systems, and these shifts have transformed the work of district and school leaders. Even under the Every Student Succeeds Act (ESSA) — the newest reauthorization of the Elementary and Secondary Education Act (ESEA) that replaced the controversial No Child Left Behind Act — states largely construct school and district quality measures using student achievement and growth (Bellwether Education Partners, 2017; Ujifusa, 2018). In response to shifting expectations around accountability reform, teacher and principal evaluation, and standards-based instruction, school leaders are now held responsible for a broader set of responsibilities and skills than ever before (Horng \& Loeb, 2010; Perilla, 2014).

Among the most notable shifts is the increasing expectation that school principals act as instructional leaders in their buildings, ultimately responsible for creating a rigorous instructional program that meet the needs of all children and develops the pedagogical capacity of all teachers (Horng \& Loeb, 2010; Perilla, 2014). Districts and state agencies also expect school leaders to ensure a positive school culture and climate. ESSA requires the inclusion of additional nonacademic measure(s) of school quality (Blad, 2016), operationalized in state plans using a diverse set of measures including chronic absenteeism (37 states), discipline and suspension rates (nine states), and student surveys (eight states) (Kostyo, Cardichon, \& Darling-Hammond, 2018). Finally, there is growing demand for a new type of school leader who works to create more equitable schools and systems for all students. Skrla, McKenzie, and Scheurich (2011) call these leaders "equity-oriented change agents," or leaders who embody equity-oriented leadership in their values and dispositions. These educators foreground their commitment to social justice and equity and avoid deficit viewsand they also reflect those values in their practice. They take part in courageous and vulnerable conversations, persist in working to remove inequities, and respect and appreciate the assets within their students and their communities (Skrla et al., 2011). Theoharis (2009) theorizes that these kinds of school leaders can oppose oppression directly and transform schools into equitable and just communities.

Given these evolving leadership roles and responsibilities, it is now more important than ever to recruit, select, and retain effective school leaders who can improve student, teacher, and school outcomes (Boyce \& Bowers, 2018; Leithwood \& Riehl, 2003; Leithwood, Harris, \& Hopkins, 2008). Toward this end, the field of educational leadership has reevaluated traditional leadership preparation programs (Grissom, Mitani, \& Woo, 2019), increased the number of privately funded programs (Crow \& Whiteman, 2016), and paid greater attention to improving systems that meet the needs of both novice and experienced school leaders (Grissom, Blissett, \& Mitani, 2018). These shifts may be manifested most clearly in the revision of professional leadership standards to ensure school administrators are prepared to work in today's $21^{\text {st }}$ century schools and center the leadership skills and competencies perceived to be most important, including efforts to improve student outcomes (Heck \& Hallinger, 2005; Murphy, Louis, \& Smylie, 2017).

Standards, typically defined as a fixed or official measure (Allen \& Sriram, 2000), occupy a critical role for guiding fair and valid forms of evidence to assess the performance of professionals. However, within the field of educational leadership, lingering questions remain about whether the 
standards are both robust and pragmatic enough to tackle the most persistent and pressing educational issues of the day (Turnbull et al., 2016). The shifting expectations for school leaders certainly represent a tall order, and there is insufficient scholarship that considers whether the revised standards adequately address this new paradigm of leadership. In this article, we engage in this very question. We use qualitative content analysis (Weber, 1990) to explore the shifting expectations for school leaders contained within the current and historical professional standards for pre-service (NPBEA, 2011, 2016) and practicing educational leaders (CCSSO, 2008; NPBEA, 2015). Given the call for equity-oriented leaders and the persistent plague of inequalities in our nation's schools, we pay particular attention to the treatment of issues related to equity and justice in the standards. We examine how the language of equity and justice-and the associated conceptions and understandings of each-has evolved over time and how the different sets of professional standards (i.e., the standards for pre-service and practicing principals) approach equity and justice differently and name and define similar issues in distinctive ways.

Because concerns related to educational equity and justice are often challenging to define, unstructured, cross-cutting, and relentless, we operationalize them as a "wicked problem" for this analysis (Weber \& Khademian, 2008). We use this framework to analyze the extent to which the professional standards shed light on the field's readiness to grapple with longstanding educational inequalities. In total, we find that although the professional leadership standards have evolved over time-and the revised standards explicitly name equity and justice more frequently than prior iterations - the current standards maintain a focus on management approaches and specific schoolbased situations. They do not adequately consider the complex and intersectional problems persistent in education nor do they address the cross-cutting and transformative change necessary to become an equity-oriented change agent. While the revised standards may represent a positive step toward equity-oriented leadership, the revisions do not establish the proper administrative authority to respond to complex issues, particularly as it relates to equity and justice. In short, even if realized in practice, the standards as currently written appear unlikely to create leaders who will affect meaningful change or address educational inequity, our education system's most wicked problem.

\section{Understanding the Context of Educational Leadership Standards}

The development of, and subsequent revision to, the standards for educational leaders has been a relatively recent occurrence. In general, the standards seek to clarify the priorities of educational leaders, especially given many competing demands on their time. For school principals in particular, day-to-day expectations and managerial tasks can co-opt much of their capacity and distract them from other more demanding and time-consuming endeavors. Nevertheless, school leaders are expected to provide direction (Young, Anderson, \& Nash, 2017), be mission-driven (CCSSO, 2008; Murphy, 2017; NPBEA, 2011, 2015, 2018; Young et al., 2017), and incorporate community-driven practices (Green \& Gooden, 2014; Khalifa, 2012).

Theoretically, the designers of the professional standards sought to make sense of these competing demands and "ensure that candidates were and are prepared to meet the demands of leadership" (Jones, 2017, p. 1). However, although "a good deal has been written [about the standards]...a relatively small amount of scholarship on the standards has been produced" (McCarthy, Shelton, \& Murphy, 2016, pp. 221-2). In the section below, we will summarize the development and evolution of the professional leadership standards and discuss the existing literature base about their impact on policy and practice. 


\section{The Evolution of Leadership Standards}

According to Smylie and Murphy (2018), an increased understanding of the nuances of the profession guided the development of the standards for educational leadership. For several decades, there was a noted disconnect between research and practice regarding what it takes to run schools well and efficiently (Murphy, 2017). The first iteration of standards, constructed in 1996, were the Interstate School Leaders Licensure Consortium (ISLLC) leadership policy standards. ISLLC was designed to bridge that gap and provide guidance to school and district leaders regarding professional expectations and best practices (Davis, Gooden, \& Micheaux, 2015; Young, Mawhinney, \& Reed, 2016). The development of leadership preparation standards followed suit in the early 2000s, developed by the Educational Leadership Constituent Council, or ELCC (Young et al., 2016). The ELCC standards were tightly aligned to the ISLLC standards, although they addressed a different audience; unlike the ISLLC standards, which focused on practicing school and district leaders, the ELCC standards were designed for leadership preparation programs (Young et al., 2016). As such, the ELCC standards were much more specific and detailed, and they more directly informed accrediting bodies and programmatic review of educational leadership programs than the ISLLC standards (Young et al., 2016).

In response to shifting professional demands for school and district leaders, the professional standards have undergone two major revisions processes in the last two decades (see Figure 1). These efforts were largely led by efforts from the Council for the Accreditation of Educator Preparation (CAEP) and the National Policy Board for Educational Administration (NPBEA), an alliance of major educational member organizations including the American Association of Colleges for Teacher Education (AACTE), the Council of Chief School Officers (CCSSO), the International Council of Professors of Educational Leadership, the National Association of Elementary School Principals (NAESP), the National Association of Secondary School Principals (NASSP), and the University Council for Educational Administration (UCEA) (NPBEA, 2018). As early as 2008, NPBEA completed a revision to the initial ISLLC standards (CCSSO, 2008). In 2015, they replaced the ISLLC standards with the Professional Standards for Educational Leaders (PSEL) (NPBEA, 2015). Following these revisions, the standards for leadership programs quickly followed suit, replacing the existing ELCC standards with the revised National Educational Leadership Preparation (NELP) standards in 2018 (NPBEA, 2018).

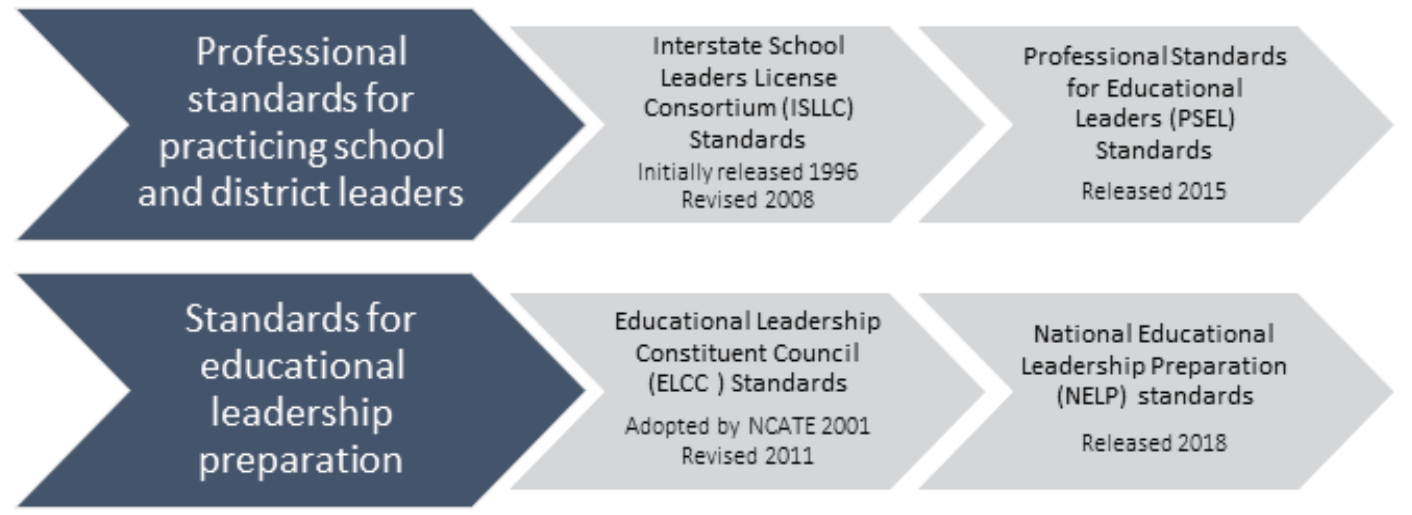

Figure 1. Evolution of standards for educational leaders.

While it is a relatively new area of study, some scholars have documented the ways the standards have evolved over time (Murphy, 2017; Smylie \& Murphy, 2018; Young, et al, 2017). One of the largest shifts has been from being solely research-driven to being both research- and practice- 
focused: The revised standards now incorporate a "more inclusive fund of knowledge from both research and the practice of leadership," while also highlighting practice and professional values (Smylie \& Murphy, 2018, p. 24). This manifests as a clearer emphasis on the day-to-day experiences of leaders and the characteristics necessary to be highly-qualified to lead a school. This practiceoriented shift has also precipitated a focus on the developmental steps and training necessary to become an effective school leader (Smylie \& Murphy, 2018).

The standards have also evolved to include a clearer vision of what it means to be a school leader. In particular, both sets of standards have embraced a more assets-oriented understanding of students and schools (Smylie \& Murphy, 2018). They have also evolved to place a greater emphasis on the dimensions of leadership that impact student success: This means centering the success of "every" student and including the supports necessary so success can be experienced by all (Smylie \& Murphy, 2018). Centering all students' success has increased the prioritization of equity-oriented practice (Murphy, 2017; Young et. al, 2017), a shift that is consistent with the increasing demand for equity-oriented change agents (Skrla, McKenzie, \& Scheurich, 2011) described in the introduction of this article. While scholars of educational leadership have taken a varied approach to defining equityoriented practice, the consensus appears to be that school and district leaders can "have a significant impact [on equity], despite educational policies, organizational cultures, and historic structures that contribute to a discriminatory educational system" (DeMatthews, 2015, p. 139).

\section{Impact of Leadership Standards on Education Policy and Practice}

Murphy (2005) called the revision to the ISLLC standards "the most significant reshaping initiative afoot in the profession during this time" (p. 154). Certainly, as McCarthy, Shelton, \& Murphy (2016) note, the educational leadership field generated a significant body of literature regarding the development and evolution of the ISLLC - and later the ELCC standards. Despite the magnitude of scholarship about the affordances of having professional leadership standards, however, most of the literature analyzes the standards themselves, rather than investigating their impact on leadership practice, policy implementation, or program improvement (McCarthy et al., 2016; Young et al, 2016). ${ }^{1}$ While the same critique could be made of the present study, the lack of empirical research regarding the effectiveness of leadership standards makes it difficult to, as Murphy (2017) writes, answer the "essential question [of] why the profession writ large and professors in particular should attend to national standards for school leaders" (p. 5).

As such, we turn to both the empirical and conceptual literature to help us understand the importance of the professional standards for school leaders. One of the most prolific scholars on this matter is Murphy $(2015,2017)$. While he "played a pivotal role in both the development and revision of the ISLLC standards" (Young et al., 2016, p. 15), and therefore is predisposed to value them, he presents two compelling reasons that the standards in general, and the development of PSEL in particular, matter to the field. First, he argues, the standards "represent consensual agreement among all the professional associations about the grounding for school administration" (Murphy, 2017, p. 5). The standards act as a sort of guideposts for the profession-elevating certain knowledge and defining the most important practices in the field. Young et al. (2017) note that in this way, the standards convey a "hidden curriculum." In other words, they implicitly highlight "a larger conception of what leadership is and what leaders do that excludes other thoughts and practices that do not fit neatly within the standards and components" (Young et al., 2017, p. 250).

\footnotetext{
1 They do note one meaningful exception here: In a statewide study of school leaders in Virginia, Owings, Kaplan, and Nunnery (2005) demonstrated that higher ratings on the ISLLC rubric were associated with higher school-level student achievement.
} 
There is a sizable body of literature, including the present article, that comments on this narrowing of leadership.

Murphy's (2017) second argument regarding the value and impact of the educational leadership standards is based on the limited literature that does document their effects on leadership policies and practices across the country. Within leadership preparation programs, the influence of the standards quickly proliferated across the states, with a substantial impact on both state licensure requirements and program approval processes and accreditation (Young et al, 2016). Within a decade of the release of ISLLC in 1996, 46 states had adopted or adapted the ISLLC standards (Murphy et al., 2009; Young et al., 2016), and this ultimately influenced licensure requirements in every state. Moreover, 16 states require prospective school leaders to pass a licensing exam aligned directly to the ISLLC standards (Young et al., 2016). Furthermore, CAEP - the national accrediting body for leadership preparation programs - relies heavily on the standards in their accreditation processes and programmatic reviews (Young et al., 2016). In this way, the standards likely have a direct effect on a vast number of aspiring school leaders.

The influence of the standards on practicing school leaders is slightly more difficult to document. Certainly, the most obvious example of this influence occurs in the adoption or adaptation of the national standards in state standards across the country (McCarthy et al., 2016) which carry real consequences for the development and evaluation of school leaders. In fact, several scholars have shown strong alignment between national leadership standards and principal evaluation systems (Derrington, \& Sharratt, 2008; Glenewinkel, 2011; McCarthy et al., 2016; Woodford, 2012). In this way, the standards "often work quite indirectly" (McCarthy et al., 2016, p. 225), by influencing the way school and district leaders conceptualize and understand their work.

\section{Theoretical Framework}

An assumption of successful school leaders is that they are able to respond appropriately to the demands of specific situations. When problems arise, effective leaders are able to make decisions by focusing on a given problem and selecting the most effective solution available (Smylie \& Murphy, 2018). However, some problems faced by educational leaders-like those regarding persistent inequalities in educational outcomes and the historical and contemporary influences of oppression in our public schools_-are not easily defined and the solutions required are not readily known. As such, these problems require a different theoretical understanding. We relied on two intersecting frameworks to understand the professional leadership standards. First, we use the wicked problems framework (Weber \& Khademian, 2008) to understand the complexity of equityoriented work within public education. Second, we rely on conceptions of equity and justice drawn from political and educational philosophy (Howe, 1997; Rawls, 1971; Young, 1990) and applied to theories of justice in both teacher education (Cochran-Smith, 2009) and educational leadership (DeMatthews, 2018; Furman, 2012). Described below, these theoretical traditions allow us to characterize the approach taken by the professional leadership standards.

\section{Wicked Problems Framework}

Definition of a wicked problem. Scholars in public policy (Weber \& Khademian, 2008) and education (Childs \& Groom, 2018) have used wicked problems as a framework to understand and explain how problems are more nuanced and complicated than first imagined. Weber and Khademian (2008) described wicked problems as unstructured, cross-cutting, and relentless complex societal or cultural issues that are difficult to solve. The public administration literature defines a wicked problem as a societal issue that is difficult to define and solve (Rittel \& Webber, 1973). The 
complexity of wicked problems challenges traditional hierarchical systems that attempt to define and ameliorate such problems (Weber \& Khademian, 2008). At first glance, the term may seem to apply a deficit perspective to challenges found in education policy; however, wicked problems and the people that are impacted by them are not morally wicked. On the contrary, it is the diabolical nature of the problems hinted at in the use of the word "wicked", as such problems are not ameliorated by standard methods of resolution (Brown, Deane, Harris, \& Russell, 2010; Rittel \& Webber, 1973).

Examples of wicked problems are pervasive throughout the public administration and management research literature. Poverty, obesity, unequal access to health care, inequality, and environmental safety are just a few societal issues that have been labeled as wicked problems because they are complex, ill-defined, have an indeterminate scope and scale, and can be interpreted in different ways depending on one's point of view (Agranoff \& McGuire, 1998, 2004; Head \& Alford, 2015; Kolko, 2012; Rittel \& Webber, 1973; Weber \& Khademian, 2008). Kolko (2012) argued that wicked problems also include incomplete or contradictory knowledge, can be significant economic burdens, and are often interconnected with other complex problems (e.g. poverty and education reform). More often than not, wicked problems do not have a final solution since any resolution can generate further issues or complexity (Brown et al., 2010). These problems tend to morph with context and time (Rittel \& Weber, 1973) and are reflective of unpredictable physical, social, economic, and geographic environments (Gibson, Smyth, Nayowith, \& Zaff, 2013).

Wicked problems are said to be unstructured because the causes and effects are extremely complicated to identify and model (Weber \& Khademian, 2008), a task which is further complicated by the fact there is typically little consensus on the problem or the solution (Head \& Alford, 2015). Wicked problems are cross-cutting because they comprise "multiple, overlapping, interconnected subsets of problems that cut across multiple policy domains and levels of government" (Weber \& Khademian, 2008, p. 336). Additionally, wicked problems are not isolated incidents or one-time occurrences. Different stakeholders, policy organizations, and government entities experience the impact of wicked problems, and as such, solutions to solve them have to come from a variety of sources (Van Bueren, Klijin, \& Koppenjan, 2003). The cross-cutting nature of wicked problems leads to a high degree of uncertainty about amelioration strategies because engaging stakeholders provokes conflicting values due in part to the variety of worldviews, political agendas, professional backgrounds, traditions, and responsibilities that are represented in diverse coalitions (Van Bueren et al., 2003; Weber \& Khademian, 2008). A wicked problem is relentless, meaning that it is not likely to be solved "once and for all," regardless of the amount of resources, authority, or expertise brought to bear on the problem (Weber \& Khademian, 2008). Despite considerable efforts to solve them, wicked problems are persistent, and while sometimes they are ameliorated, these problems are never fully resolved (Head \& Alford, 2015; Van Bueren et al., 2003). The consequences of wicked problems also affect other policy arenas (Weber \& Khademian, 2008). Conventional structures and systems within the public sector are not designed to address the tasks of conceptualizing, mapping, and responding to wicked problems (Head \& Alford, 2015), thus leading to temporary and imperfect resolutions when addressing these issues.

Conceptualizing educational inequality as a wicked problem. Nowhere in education is this understanding of wicked problems more apropos than the persistent inequalities and opportunity gaps that have plagued our education system since its earliest days. Those inequalities are so vast that in 2009, Secretary of Education Arne Duncan referred to them as the "civil rights issues of our generation" (Confirmation of Arne Duncan, 2009, p. 9). The extent of these inequalities are well-documented-for a longer discussion, see Carter and Welner's (2013) edited volume-and they certainly represent an unstructured and cross-cutting societal issue. In fact, scholars attribute inequalities in student outcomes to a wide variety of potential causes, including chronic 
underfunding, inequitable resource allocation, and unequal distribution of teachers and high-quality instruction (Darling-Hammond, 2013). Certainly, structural forces like racism, heteronormativity, and implicit bias also play a role in the creation of systems that distribute access and opportunities unequally to marginalized students and communities (Kantor \& Lowe, 2013).

Educational inequality is also relentless. Despite an intense focus in education research and practice, documented inequalities persist at levels consistent with those seen prior to the 1956 Brown decision. To better prepare us to address the relentless nature of inequality in public education, Ladson-Billings (2008) advocates that we abandon the apolitical language of the achievement gap. Instead, she argues we should conceive of inequalities in student outcomes as an education debt, which "requires us to think about how all of us, as members of a democratic society, are implicated in creating these achievement disparities" (p. 236). This reconceptualization may help educators and society at large take a wider view of educational equity — and the complex and intersecting forces that make it so challenging to find solutions.

While not clearly articulated in the literature, the understanding of inequality as a wicked problem is consistent with the proliferation of work within educational leadership as it relates to social justice (Furman, 2012; Theoharis, 2007) and the associated demand for inclusive, equityoriented leaders. Accordingly, several obstacles interfere with the creation of equity-oriented leaders. First, most practicing principals are not equipped with the knowledge or skills to become these kinds of leaders (Darling-Hammond, Meyerson, LaPointe, \& Orr, 2010; Quin, Deris, Bischoff, \& Johnson, 2015). Furthermore, despite a significant investment in educational leadership preparation programs, this same literature also suggests that many traditional and alternative preparation programs do not adequately prepare prospective school leaders for equity-oriented, inclusive leadership (DarlingHammond et al., 2010; Quin et al., 2015). It is no wonder, then, that many acting school leaders struggle to maintain a focus on equity and inclusion (Billingsley \& McLeskey, 2014; CambronMcCabe \& McCarthy, 2005; DiPaola \& Walther-Thomas, 2003), particularly when juggling competing demands and complex political climates.

Another challenge to creating equity-oriented leaders may stem from the argument that, to a certain extent, "leadership and inclusion are not natural bedfellows" (Ryan, 2012, p. 9). In other words, a host of challenges prevent equity-oriented work from taking root-including outdated approaches to management, frameworks that rely too heavily on individuals to enact fundamental change, and a general "reluctance to recognize, or acknowledge exclusive practices like racism, sexism, classism, homophobia, ableism” (Ryan, 2012, p. 12). Ryan and Higginbottom (2017) elaborate:

It is not easy, at the best of times, for educators to promote inclusion, equity, and social justice in contemporary institutions that continue to display racist, sexist, classist, and homophobic policies, cultures, traditions, and practices (Ryan, 2012; Theoharis, 2007). But changing these practices is complicated by the way in which education organizations work.... (pp. 103-104)

\section{Conceptions of Equity and Justice in Educational Leadership}

Uncertainty within the field. To build upon these critiques, we wondered if one of the challenges to creating inclusive, equity-oriented leaders is a lack of clarity within the field-including the professional standards - regarding the very concepts of equality, equity, or justice. Several other scholars, across educational traditions, have likewise criticized education for persistently failing to define social justice (Bogotch, 2002; Cochran-Smith, 2009; Furman, 2012; North, 2006; Zeichner, 2009). Furman (2012) acknowledged that the importance of social justice in educational leadership is widely recognized and generally understood to focus on the educational experiences and disparities 
in educational outcomes for traditionally underserved students. Nevertheless, he noted that "its specific nature remains elusive" (p. 194).

This cause of the uncertainty within the field appears to be multi-faceted. First, much of the literature lacks an explicit connection to the "philosophical and political roots of social justice education" (Cochran-Smith, 2009, p. 445). Without those connections, it can be difficult for scholars and practitioners to articulate what equity and justice look like or to develop strategies to increase them in practice. Second, the literature regarding the development or evaluation of social justice leadership is "thin" (Furman, 2012). To make sense of social justice within the present study, we relied on literature from political and educational philosophy (Howe, 1997; Rawls, 1971; Young, 1990), teacher education (Cochran-Smith, 2009), and educational leadership (DeMatthews, 2018; Furman, 2012).

Theories based upon principles of distribution and recognition. Both Cochran-Smith (2009) and DeMatthews (2018) attempt to deepen the empirical and conceptual work in their respective fields - teacher education and educational leadership - by grounding it in the rich philosophical traditions of justice and equity. Both works synthesize theories of social justice into two dominant ideologies - those based upon distribution and others based upon recognition. A distributive conception of social justice aligns mostly clearly to the theoretical tradition started by John Rawls (1971) in his influential A Theory of Justice. Rawls (1971) broadly defines social justice as equality in the distribution of rights and advantages. The solution to injustice, then, is the "redistribution of material and other goods, including opportunity, power, and access with the goal of establishing a society based on fairness and equality" (Cochran-Smith, 2009, p. 450). Examples of educational programs built upon a distributive paradigm include compensatory programs like Head Start or bilingual education programs (Cochran-Smith, 2009).

On the other hand, theoretical orientations rooted in recognition characterize injustice as both structural and as an inherent failure of society to recognize and respect social groups (CochranSmith, 2009; DeMatthews, 2018; Young, 1990). Young (1990, 2011) criticized distributive approaches to equality for being inadequate_or even counterproductive-because they "presume to know what is good for everybody... [and can therefore] work to deny difference and foster the oppression of social groups" (Cochran-Smith, 2009, p. 450). Moreover, distributive approaches that focus entirely on structures fail to acknowledge the way that individual actors can oppress groups via exploitation, marginalization, powerlessness, cultural imperialism, and violence (Young, 1990).

\section{Methods}

In this article, we use the wicked problems framework to examine the extent to which the revised PSEL and NELP standards capture the challenging work required for school leaders to act as inclusive, equity-oriented change agents (Maxwell et al, 2013; Skrla et al., 2011). Guided by our theoretical framework, we utilized a deductive qualitative content analysis approach (FinfgeldConnett, 2014; Hsieh \& Shannon, 2005; Maier, 2018; Weber, 1990) to examine the content of the historical and revised leadership standards, particularly as it relates to issues of equity and justice. These analyses sought to answer two research questions. First, to what extent do the professional leadership standards address or acknowledge issues related to equity and justice? Second, what conceptions of equity and justice are implicit in the professional leadership standards? For each question, we paid particular attention to the evolution of the standards over time and differences across standards for pre-service and practicing leaders. Below, we describe the data sources, coding procedures, and analytical approach in more detail. 


\section{Data Sources}

We collected the data for this article as part of a larger in-progress study focused on the evolution of data use and assessment within principal leadership standards. For the present study, we focused our analyses and findings on data regarding equity and diversity, broadly conceived. We utilized published standards documents from four sources presented above in Figure 1): (a) the 2011 ELCC Educational Leadership Program Standards (NPBEA, 2011); (b) NELP (NPBEA, 2018), the 2018 revision of the ELCC standards; (c) the 2008 ISLLC Educational Leadership Policy Standards, generally adopted for in-service leaders (CCSSO, 2008); and (d) the 2015 ISLLC revision, the PSEL standards (NPBEA, 2015). Table 1 presents a summary of the textual data included in these four documents.

Table 1

Summary of data sources included

$\begin{array}{cc}\text { Educational Leadership } & \text { Educational Leadership } \\ \text { Preparation Standards }- & \text { Standards for Practicing Leaders } \\ \text { Building-Level } & \end{array}$

\begin{tabular}{lcccc}
\hline Document & 2011 ELCC & 2018 NELP & 2008 ISLLC & 2015 PSEL \\
Reference & NPBEA, 2011 & NPBEA, 2018 & CCSSO, 2008 & NPBEA, 2015 \\
Adoption & 2011 & 2018 & 2008 & 2015 \\
N Standards & 7 & 8 & 6 & 10 \\
N Elements/Components & 28 & 25 & 31 & 83 \\
Word Count & $<37,000$ & $<45,000$ & $>1,000$ words & $<8,000$ words \\
\hline
\end{tabular}

\section{Coding Procedure}

We first reviewed the full text of each set of standards to collect textual evidence and examples where the standards addressed equity and justice. To collect this evidence, we reviewed each standards document in its entirety and pulled out all relevant and surrounding text (e.g., if a particular standard mentioned equity, we selected text from the entire standard). We also doublechecked these selections by searching each document for relevant keywords-and all of their associated variations (e.g., to search for equity, we also searched for "equitable," "equitably," and "equit*"). In particular, these confirmatory keyword searches included three major categories: (a) equity and justice, including equity, equality, justice, inclusion; (b) identity and culture, including diversity, race, culture, and gender; and (c) ideologies and causes of inequality, including racism, oppression, achievement, opportunity, and asset. For each passage that included one of these keywords, we confirmed that it had not been inadvertently omitted from the collection of relevant passages.

To allow for re-coding and stronger interpretation, we then organized the selected passages into a single table. This table presented data across all four standards documents in a single location to enable comparisons across time and audience. The tables also included short analytical memos written after the coding process was complete. We then deductively coded the text to characterize the conceptions of equity and justice present in each passage, with some passages evoking more than one idea. 


\section{Analytical Approach to Content Analysis}

After the evidence was collected and deductively coded, we first calculated counts of the key words described above; these are presented in Table 2 within the findings section. While counts of key words represent only a basic approach to content analyses, they yielded some meaningful insights regarding the evolution of the standards and the prioritization of certain concepts over time. We then analyzed the coded text for trends and compared results across two dimensions: time [i.e., contrasting revised standards (NELP and PSEL) to their prior versions (ELCC and ISLLC, respectively)] and target audience [i.e., comparing the in-practice educational leadership standards (PSEL and ISLLC) to the leadership preparation standards (NELP and ELCC). This analysis was completed through memoing and member checking conversations among the three authors.

Applying relevant theories of social justice. As noted above, the initial selection of evidence and coding of relevant passages was conducted deductively; that is, we did not apply a specific theoretical framework of equity and justice to analyze the standards documents. In fact, one primary aim of our research was to characterize the approach taken within the professional leadership standards regarding issues of equity and justice, rather than applying a priori definitions to evaluate them. This approach was also consistent our designation of educational equity as a wicked problem (Weber \& Khademian, 2008), which means it is a complex, nearly intractable social problem that is particularly difficult to define.

Following our initial deductive coding, however, we relied on the conceptions of justice outlined above and drawn from political and educational philosophy (Howe, 1997; Rawls, 1971; Young, 1990), teacher education (Cochran-Smith, 2009), ${ }^{2}$ and educational leadership (DeMatthews, 2018) to organize our results and describe the underlying conceptions of justice contained within each. In particular, we used these frameworks to consider (a) whether the professional standards relied most heavily on conceptions of justice based on distribution or recognition, (b) the extent to which they unpacked what equality means and for whom, and (c) whether they acknowledged the importance of recognition across various identity groups. We also explored whether the standards recognized the role of students and families-particularly those from traditionally marginalized communities - in defining which opportunities they want equalized (Howe, 1997). Finally, we examined how these conceptions of equity manifested in various types of professional practices, linked to the Cochran-Smith's (2009) framework.

Applying the wicked problems framework. In order to make sense of the findings, particularly with regard to the conceptualization of equity and justice within the professional leadership standards, we relied on the wicked problems framework. This provided a lens to question how well the professional standards prepare pre-service and practicing leaders to grapple with complex, cross-cutting, and persistent problems like educational equity. In particular, we considered the extent to which the standards treated equity as a complex problem versus a tactical policy puzzle.

\section{Findings}

Below, we organize our findings by our research questions and the interpretative framework borrowed from Cochran-Smith (2009) and DeMatthews (2018). First, we present results regarding the extent to which the professional leadership standards address or acknowledge issues related to

2 While initially developed for teacher education, we find the organization of Cochran-Smith's (2009) framework particularly useful for the study of principal standards, especially given the evolving role of principals as instructional leaders-who support and scaffold teacher learning - in school buildings. 
equity and justice, with particular attention to the evolution of standards over time. We then present results regarding the conceptions of equity and justice implicit within the professional leadership standards, including results related to the underlying theoretical conceptions of justice and the conceptions of professional practice. Consistent with other scholars (Davis, Gooden, \& Micheaux, 2015; Murphy, 2017; Young et al., 2017) and the documentation contained within the revised standards, we find an increased focus on equity and inclusion within both sets of standards, including those designed for leadership preparation programs and those for practicing school leaders. Second, we find some evidence of a broadened conception of equity and justice-within both the revised PSEL standards (NPBEA, 2015) and the revised NELP standards (NPBEA, 2018). Both sets of standards contain different changes, however, suggesting that standards developed for different purposes (i.e., for practicing principals versus for leadership preparation programs) may define the role of equity-oriented leaders differently or may have different expectations for practice.

\section{Attention to Equity and Justice in Professional Leadership Standards}

Overall, all four sets of professional leadership standards addressed and acknowledged equity and justice explicitly. Furthermore, our analyses suggest the newest generation of professional leadership standards more frequently and more directly addressed equity and inclusion than their prior iterations. To quantify the increased foci of the standards on equity, we first compared the frequency of key phrases and language within each set of standards (Table 2).

Table 2

Word frequency tied to key concepts within each set of standards, excluding references or glossary

\begin{tabular}{|c|c|c|c|c|}
\hline \multirow[b]{2}{*}{ Concept \& Associated Words } & \multicolumn{2}{|c|}{$\begin{array}{l}\text { Educational Leadership } \\
\text { Preparation Standards }\end{array}$} & \multicolumn{2}{|c|}{$\begin{array}{l}\text { Practicing Leader } \\
\text { Standards }\end{array}$} \\
\hline & ELCC & NELP & ISLLC & PSEL \\
\hline \multicolumn{5}{|l|}{ Equity \& Justice Concepts } \\
\hline "Equity/equitable" & 27 & 174 & 1 & 14 \\
\hline "Equality" & 0 & 6 & 0 & 0 \\
\hline "Justice" & 19 & 0 & 0 & 2 \\
\hline "Inclusion/inclusive" & 5 & 72 & 0 & 2 \\
\hline \multicolumn{5}{|l|}{ Identity \& Cultural Concepts } \\
\hline "Diverse/diversity" & 47 & 59 & 4 & 3 \\
\hline "Race/racial" & 3 & 1 & 0 & 1 \\
\hline "Culture/cultural" & 36 & 83 & 2 & 18 \\
\hline \multicolumn{5}{|l|}{ Root Causes \& Ideologies } \\
\hline "Racism" & 0 & 0 & 0 & 0 \\
\hline "Oppression" & 0 & 0 & 0 & 0 \\
\hline "Achievement" & 35 & 5 & 0 & 5 \\
\hline "Opportunity" & 29 & 59 & 0 & 13 \\
\hline "Asset/deficit" & 1 & 4 & 0 & 2 \\
\hline
\end{tabular}

Note: These frequencies were calculated by excluding text contained in references and glossaries. They therefore represent only the text directly from the standards or associated elements or components, and the narrative text surrounding the standards (e.g., the research support sections or the associated knowledge and skills). 
While word counts provide only a small slice of the rich content included within the standards, several interesting trends emerged from this initial comparison. First, over time, both the pre-service and practicing leader standards increased in their total references to equity and justice. While more pronounced in the standards for educational leadership programs, we found an increased focus on issues related to social justice in both the revised NELP (NPBEA, 2018) and PSEL (NPBEA, 2015) standards. This shift was seen in the frequency of references and also in the nature of the discussion, which we describe in greater detail in the section that follows. Most notably, we found dramatic increases in the number of references to equity, inclusion, and culture. For example, the 2011 ELCC standards (NPBEA, 2011) mentioned equity-and other associated words with a shared stem - just 27 times. Seven years later, however, the revised NELP standards referred to equity over 170 times. While the NELP standards were longer than their predecessor, the total word count only increased by roughly $20 \%$, compared to a more than $500 \%$ increase in the use of equity. Moreover, the revised PSEL standards include an entirely new standard, "Standard 3: Equity and Cultural Responsiveness," that delves into the role of an educational leader in creating and maintaining equitable environments.

We also found that both the NELP (NPBEA, 2018) and PSEL (NPBEA, 2015) standards were more likely to reference culture than their previous versions, and the NELP standards were much more likely to reference inclusion or inclusive education. In fact, inclusion or related words appeared in the NELP standards 72 times - a rapid expansion from 5 times in the prior version. The PSEL standards, on the other hand, rarely mention inclusion - that phrase only appeared twice, once in reference to setting a school mission and vision and then again with regarding to creating supportive school communities. Interestingly, despite the increased reference to equity, equality, and inclusion, the revised NELP standards contain considerably fewer references to justice-something that we did not find within the PSEL standards. We suspect this reflects the evolution of discourse within educational leadership, which now more directly names equity and equality in lieu of the more open-ended terminology evoked by “justice." We cannot speculate, however, why this trend was only seen in the standards for pre-service and not practicing leaders.

In general, these trends are consistent with the limited literature already published regarding the revised standards (Davis, Gooden, \& Micheaux, 2015; Murphy, 2017; Young et al., 2017). In their examination of the connection between the revised NELP standards and the educational leadership research base, Young et al. (2017) found a similar trend, noting that the new NELP standards "stand in stark contrast to previous preparation standards" by focusing more intentionally on "equitable access to resources, relationships, opportunities, and supports necessary for success, as well as supporting the development of responsive and equitable practices among teachers and staff' (p. 232). The introduction of the revised NELP standards also highlights the elevation of equity in the revised standards, something accomplished in part by breaking ethics and equity into two standards: One focused on ethics (standard 2) and the other on equity and cultural leadership (standard 3).

\section{Theoretical Conceptions of Justice}

Having documented the increased prevalence of language regarding equity and justice, we then sought to understand the underlying conceptions of equity and justice inherent in the professional leadership standards. Across all four sets of standards, three broad conclusions emerged. First, each set of standards at some point evoked ideas of equity and justice without clearly defining what those concepts mean. Second, when we were able to determine an underlying conception of justice, we found that all four documents relied most often on distributive understandings (Rawls, 1971), rather than upon theoretical frames related to recognition (Howe, 
1997; Young, 1990). Finally, despite the prevalent focus on distributive conceptions of justice, we found that the underlying conceptions of equity and justice contained within the documents evolved between initial standards documents (i.e., ELCC and ISLLC) and their revised counterparts (i.e., NELP and PSEL). In what follows, we unpack each of these themes more deeply.

Unclear or ill-defined conceptions of justice. In keeping with the concerns of scholars who note that education often fails to define concepts of equity or justice (Bogotch, 2002; CochranSmith, 2009; Furman, 2012; North, 2006; Zeichner, 2009), our analyses suggest that these ideas are often unclear or left undefined in the professional standards documents for school leaders. This uncertainty appeared in both original and revised standards documents, and within those for practicing school leaders and those written for pre-service students in educational leadership programs. However, the revised NELP standards (NPBEA, 2018) were most likely to reference equity or justice in a manner that did not allow us to classify the underlying conception of justice inherent in the text. In fact, within the NELP standards, we were unable to classify the underlying conceptions of justice more often than not-something that sets them apart for any other set of standards, new or old. While the analyses described above suggest the NELP standards mentioned equity and inclusion much more often than any other document, we also found that these references often remained undefined and the surrounding text frequently lacked contextual clues to make sense of it. For example, NELP calls for educational leadership program completers who are able to evaluate, develop, and implement a wide range of practices-including those related to the establishment of a mission and vision (Standard 1), curriculum (Component 4.4), instructional practices (Component 4.2), assessments (Component 4.3) —all of which "support" or "reflect" equity. In these places, however, equity is not defined, and it is unclear which conceptions of justice undergird the standards.

Prioritization of distributive conceptions of justice. Across all four standards documents, the vast majority of references to equity and justice relied on conceptions of justice based in a distributive framework. In fact, the ISLLC (CCSSO, 2008), ELCC (NPBEA, 2011), and PSEL (NPBEA, 2018) standards relied almost exclusively on a distributive conception. Within the original ELCC and ISLLC standards and elements, conceptions based on recognition appear only once apiece, and they are absent from the NELP standards. While the PSEL standards took a more balanced approach, the number of passages coded as distribution still substantially outnumbered those coded as recognition.

In our data, we most often classified the standards as espousing a distributive conception of justice when they described equal access to resources, curriculum, or opportunities; in these passages, the standards evoked concepts of fairness and equal opportunity. For example, the PSEL standards (NPBEA, 2015) expect practicing leaders to ensure "each student has equitable access to effective teachers, learning opportunities, academic and social support, and other resources necessary for success" (p. 11), while the NELP standards (NPBEA, 2018) call for program completers to advocate for "equitable resourcing plans" and to "ensure that each student has equitable access to educational resources, technologies, and opportunities" (p. 15). These distributive conceptions appear in both the standards themselves and the identified knowledge, skills, and research support sections aligned to each standard. For example, NELP expects candidates to have knowledge regarding differentiation and accessible assessments, and asks that they "analyze how law and policy are applied consistently, fairly, equitably, and ethically" (p. 26). Sections focused on supportive and equitable school cultures also utilize a distributive conception, asking principals to "use data to evaluate" school cultures and ensure that students are "treated fairly" by using "equitable guidelines, procedures, and decisions" (NPBEA, 2018, p. 86). These statements all define 
equity as the equal distribution of goods-including learning opportunities, resources, and teaching — or the reduction in inequalities (e.g., the assurance that discipline is fairly distributed among students).

Evolving conceptions of justice over time. Despite the general focus on distributive justice across all four documents, we found that the professional standards have evolved over time with regard to their underlying conceptions of justice. Most obviously, the revised PSEL (NPBEA, 2015) standards were the first to rely in a meaningful way on conceptions of justice based on recognition (Howe, 1997; Young, 1990), rather than almost exclusively focused on distribution like both prior iterations (ELCC; NPBEA, 2011; or ISLLC: CCSSO, 2008). More so than any other set of standards, PSEL calls for a new kind of equity-oriented leader, who moves beyond distributive ideas and possesses a rich "understanding of each student's culture and context" (p. 11), recognizes "each student's strengths, diversity, and culture as assets" (p. 11), and creates a culture where "each student is known, accepted and valued, trusted and respected, cared for, and encouraged to be an active and responsible member of the school community" (p. 13). The NELP standards (NPBEA, 2018), on the other hand, maintained a primary focus on distributive conceptions of justice, despite being much more likely to reference equity and inclusion overall.

Beyond this fundamental shift in the conception of justice writ large, we also found that the standards evolved in other ways. For example, even within a broader conception based on distributive justice, we found shifting conceptions of which goods ought to be distributed. Of note, both NELP (NPBEA, 2018) and PSEL (NPBEA, 2015) focused more heavily on student and teacher opportunity - rather than just achievement- than their earlier versions. For example, both NELP and PSEL acknowledges opportunity structures in their standards regarding equitable access, as cited above. In this way, the focus is not just on ensuring equal outcomes for all students, as is often suggested in the ELCC (NPBEA, 2011) and ISLLC (CCSSO, 2008) standards-but also on ensuring equal opportunities as well. This reframing is consistent with the field's reframing of the achievement gap in favor of the opportunity gap and education debt (Carter \& Welner, 2013; Darling-Hammond, 2013; Ladson-Billings, 2008).

\section{Conceptions of Equity-Oriented Professional Practice}

Cochran-Smith (2009) criticizes much of the current policy language-particularly following the NCLB-era of federal accountability reform - for narrowly defining teacher practice by two features: subject-matter knowledge and teaching skills. She broadens this conception, arguing that practice exists as a more complicated interaction between four things: (a) knowledge, (b) skills, (c) interpretative frames, and (d) advocacy with and for students, families, and communities (CochranSmith, 2009). In our analyses, we found that the professional standards addressed each of these four areas of practice, although they did not equally emphasize each. Moreover, we found some differences in the professional practices prioritized in the standards documents.

Prioritization of leadership knowledge and skills. Consistent with the trends CochranSmith (2009) identified in the policy discourse surrounding teachers, each of the four standards documents we analyzed focused most heavily on the acquisition and demonstration of professional knowledge and skills, rather than advocacy or interpretative frames. Notably, the standards for practicing leaders [i.e., ISLLC (CCSSO, 2008) and PSEL (NPBEA, 2015)] focused almost exclusively on skills related to equity and justice, while those for pre-service leaders [i.e., ELCC (NPBEA, 2011) and NELP (NPBEA, 2018)] focused on skills but also included the knowledge necessary for school leaders to accomplish equity-oriented work. This focus on knowledge may be reflective of the mission of standards for initial licensure programs, who are often tasked with distilling knowledge to 
new educational leaders. For example, ELCC and NELP include numerous elements or standards that ask candidates to both understand and act in various ways (e.g., "candidates understand and can mobilize community resources by promoting an understanding, appreciation, and use of diverse cultural, social, and intellectual resources within the school community" (ELCC; NPBEA, 2011, p. 16).

Despite the universal focus on knowledge and skills, we also found some changes in the specific kinds of skills or types of knowledge contained within the standards over time. For example, while the ELCC standards (NPBEA, 2011) referenced "cultural competence" 10 times, the revised NELP standards (NPBEA, 2018) never used this phrase, electing to use culturally responsive or culturally relevant instead. In fact, the concept of cultural competence has been criticized in education, with scholars noting it may assume homogeneity among cultural groups and often fails to acknowledge the role of structural forces and inequalities (Fisher-Borne, Cain, \& Martin North, 2014; Gorski, 2016). As such, the revised standards include the appearance and relative prioritization of culturally responsive practices, something that pushes upon conceptions of cultural competence included in the prior versions of the standards.

Another noteworthy shift in the standards is the appearance of gender diversity and gender identity-concepts totally absent from prior iterations. This change is particularly noteworthy given the increased attention to the safety issues for LGBTQ students in general and transgender and gender nonconforming students in particular. The revised standards also shifted their focus on reaching the whole child, rather than maintaining their previous preoccupation with academic skills. While the earlier versions of the standards focused almost exclusively on outcomes related to student learning, the NELP standards in particular broaden the conceptions of student success to include both academic outcomes and the "well-being of each student and adult" (NPBEA, 2018, p. 121). This shift was highlighted by Young et al. (2017) as well, who note that it "provides an important counterweight to the insistent and incessant influence of high-stakes accountability" (Young et al., 2017, p. 250).

Leadership dispositions and interpretative frames. Relevant interpretative frames for educational leaders include the ideas that "all students can learn academically challenging material ... [and] asset-based (as opposed to deficit-based) view[s] of the cultural, linguistic, and experiential backgrounds of students" (Cochran-Smith, 2009, p. 456). While these interpretative frames were not commonly stated within the original ELCC (NPBEA, 2011) and ISLLC standards (CCSSO, 2008), we found evidence that they emerged in the revised PSEL standards (NPBEA, 2015). While not explicitly included in the language of the revised standards and elements of NELP (NPBEA, 2018), these frames were prevalent throughout the accompanying research support. This shift coincides with a renewed focus within educational leadership on the needed dispositions among school leaders, rather than simply on skills for equity and justice (Capper, Theoharis, \& Sebastian, 2006).

Excerpts regarding equity-oriented interpretative frames most often co-occurred with conceptions of justice centered on recognition, and largely focused on valuing and recognizing students' identities, families, and cultures. In at least one excerpt, the standards called on school leaders to recognize and address the "institutional biases of student marginalization [and] deficitbased schooling" (PSEL 2015; NPBEA, 2015, p. 11). NELP further suggests that to ensure equity, prospective school leaders must “support the development of teachers' and staff members' ability to recognize, respect, and employ each student's strengths, diversity, and culture as assets for teaching and learning" (emphasis added, NPBEA, 2018, p. 87). This language represents a significant shift in both sets of revised standards toward asset-based thinking, consistent with the increased frequency seen in Table 2. This focus on asset-based thinking is also apparent in Murphy's (2017) discussion of 
the development of the PSEL standards. He contends that contained within the PSEL standards is the idea that any school mission should

reflect asset-based thinking about students and the larger community... At the beginning of the modern era of school improvement, this third core idea pushes

back against the deficit-based thinking often found in struggling or failing schools and schools with large numbers of students placed at risk. It is anchored on the belief that all students are capable of learning, that the school does not underestimate the abilities and efficacy of children. (p. 14)

This turn is an important one in the evolution of the leadership profession's perceptions of students of color, low income students, students with disabilities, English language learners, and other students traditionally underserved in schools.

Advocacy and equity as a wicked problem. Within educational leadership, standards that call on leaders to be advocates might require them to "call explicit attention to school and classroom injustices and work actively with their students, other teachers, parents, and community groups to pursue justice goals" (Cochran-Smith, 2009, p. 457). While less common than a focus on knowledge and skills, all four sets of standards included language that addressed the role of school leaders as advocates. In terms of frequency, we found an increased focus on advocacy within the revised standards - particularly the NELP standards for educational leader preparation programs (NPBEA, 2018). In fact, the word "advocate" and its various derivations appears more than 100 times in the NELP standards.

However, the nature of this advocacy appears to have evolved, something noted in the introduction to the NELP standards:

In contrast to ELCC, the 2018 NELP standards (see component 6.3) require building-level leaders to "reflectively evaluate, communicate about, and implement laws, rights, policies, and regulations to promote student and adult success" but does not expect building-level leaders to act to influence those laws, rights, policies, and regulations (NPBEA, 2018, p. 6).

While both ELCC and ISLLC encouraged school leaders to act to change and influence broader policies and political climates, the new standards appear to focus school leaders' efforts closer to their onus of control. Like Cochran-Smith (2009), this may be a recognition that it is challenging for educators alone to "substantially fix the schools or alter the life chances of students" (p. 457). However, it remains unclear if the revised standards expect school leaders to "join with others as part of larger social movements for change" (Cochran-Smith, 2009, p. 457).

\section{Discussion \& Conclusion}

As we outlined in the opening of this article, school leaders are now expected to do more than ever before-they are expected to become instructional leaders, school climate experts, and change agents. Implicitly, we may be asking them to undo centuries-old challenges, including opportunity gaps, chronic absenteeism, and family and student disengagement; the list could go on. Even in the best circumstances, leaders struggle with competing demands and limited resourcesincluding time, expertise, and influence. Given these shifting expectations, though, it may be more important than ever for the professional standards to clarify expectations and highlight the power of leadership. Yet, it remains uncertain if the professional standards — which have been heavily revised in the last five years_-adequately capture the work needed for education leaders to tackle the 
persistent and most chronic problems facing education today, including those related to equity and justice in our schools.

Our analyses sought to wrestle with some of these very questions. Overall, we found that the treatment of educational equity and justice within the professional leadership standards has evolved and changed in several ways. Both the PSEL (NPBEA, 2015) and NELP standards (NPBEA, 2018) have elevated the importance of equity and broadened the conceptions of equity-oriented practice to focus more thoughtfully on cultural responsiveness, opportunity, and asset-based approaches. The PSEL standards in particular have also expanded their conception of justice to acknowledge the virtue of recognition (Howe, 1997; Young, 1990). While the impacts stemming from that shift on professional practice remain uncertain, it is certainly in keeping with the recommendations of leading scholars in the area of justice within education.

Both Cochran-Smith (2009) and DeMatthews (2018) have argued that educators should attend to both recognition and distribution in efforts to lead classrooms, schools, and educational organizations in a just and equitable manner. Each conception highlights persistent, wicked challenges in our schools: As DeMatthews notes, "the equitable distribution of goods and resources and the full recognition of all students and families remain a significant challenge within schools, particularly those in low-opportunity communities of color" (p. 138). While our analyses do suggest the standards have begun to shift in this regard, we still find that they maintain a focus on distribution. Moreover, the concepts of equity and justice often remain unclear within the documents. This lack of clarity could have important implications for practice: Cochran-Smith (2009) warns that when terms like equity and justice go undefined, positive work that occurs to foreground these principles may exist "in name only... or [be] diluted, trivialized or co-opted" (Cochran-Smith, 2009, p. 445). Cochran-Smith further reminds us that if we do not intentionally recognize the underlying conceptions of justice-and work to connect distribution to recognitionwe may focus on distributing the wrong resources and outcomes (e.g., access to a biased or deficitoriented curriculum).

Despite these challenges, our analyses suggest that the shifts contained within the standards and outlined in this article are generally well-aligned to the demand for equity-oriented change agents (Maxwell et al, 2013; Skrla et al., 2011). In this way, they represent progress and we find them to be commendable. However, the sum of our findings leave us uncertain about the ability of the standards - even with the shifts noted above - to inspire the kinds of transformative change needed for school leaders to wrestle with wicked problems, particularly as it relates to systemic and structural oppression. This uncertainty is rooted less in what is present in the standards than in what is missing or underdeveloped. For example, while our analyses and prior work by Murphy (2017) suggest that the revised standards reinforce asset-based understandings of students and families, the standards still largely frame the relevant assets as students' capabilities and intellectual accomplishments. In this way, they push the profession toward optimism around students' abilities and academic potential, but do not necessarily question the way we measure or conceptualize the most important outcomes. In short, they fail to heed Cochran-Smith's (2009) warnings that certain approaches may mistakenly lead us to believe that "'equal access to a faulty curriculum' ...constitute[s] justice" (p. 453).

Moreover, both sets of standards largely eschew direct references to race in favor of discussions regarding the "diversity" of students. In fact, the introduction to the NELP standards (NPBEA, 2018) addresses the fact that they do not name subgroups, claiming that "because a school leader must improve the learning of all students, the standards purposefully do not name specific sub-groups of students" (p. 7). The glossary of terms does define diversity to include various subgroups, but this feels like an afterthought rather than an intentional choice. Moreover, that same 
definition places race and ethnicity in the same category as student and adult "interests," a grouping that ignores the systemic and oppressive forces at play and discounts the need to recognize the identities and lived experiences of one of those groups (Young, 1990). While NPBEA (2018) argued that the NELP standards provided a unique opportunity for leadership preparation programs to prepare leaders to have conversations about race, our analysis questions the degree to which the revised standards could actually stimulate such a discussion.

In addition to not attending to race, the standards also do not necessarily ask leaders to disrupt the status quo. In fact, as noted above, the revised standards appear to diminish the role of leaders in influencing policy or state and national change. In total, these findings cause us to question to extent to which the current leadership standards prepare school leaders to think beyond the realities that exist within their schools and begin to tackle the wicked problems that exist and pervade our society and school system. Young, Anderson, and Nash posed a similar question in 2017, asking whether educational leadership preparation programs are designed "to prepare leaders for the world in which they will work, or is it to develop leaders who can think beyond what currently exists_-transforming education as we know it?" (p. 228). Like them, we believe leadership can and should engage with world "as it currently exists" while also using their positions to "imagine and create their own futures" (p. 229). In response to this, Young et al. (2017) urged educational leadership faculty members "to take on the important work of both using the standards to prepare leaders for the systems in which they will work, while also developing their ability to rethink, reimagine, and transcend those systems" (p. 251). To enable educational leaders to "rethink, reimagine, and transcend" the current status quo in education, Young et al. recommended intentionally supporting three propensities for aspiring candidates: critical reflection, critical consciousness, and multiple perspective taking. We see a clear connection between these propensities and the wicked problems framework: Each would allow leaders to take a more complex look at the unstructured, cross-cutting, and relentless wicked problems within education than what is currently contemplated in the standards.

\section{Limitations, Additional Research, and Contributions to the Field}

We acknowledge a few limitations to our study and want to address those here. First, we acknowledge that the field must be careful not to position principals as superheroes (Gooden, 2012; Green, 2015; Ishimaru, 2013), especially when it comes to incorporating equity and race-based practices into their day-to-day practices. Quite simply, equity-oriented change agents cannot "save" education singlehandedly. It is therefore important not to presuppose that school leaders-even the very best ones - can "solve" the wicked problem of educational inequality. Second, we also recognize the NELP standards (NPBEA, 2018) were only introduced in 2018, and there is still ongoing conversation regarding the utility and functionality of them, especially as it relates to the preparation of future school leaders. Third, our data collection and analysis plan were limited to examining the standards documents as they were written (Malen, 2002). This decision allowed us to focus on examining the standards through our conceptual framework; however, we recognize that interview or survey data of school leaders regarding their understandings of the standards would have helped provided a richer context and discussion. Finally, we did not directly seek out the creators or developers of the standards to get their insight on the development and execution of the standards; we instead relied heavily on their writing as manifested in the standards and accompanying scholarship (e.g., the scholarship of Murphy and Young). Future research could gain a depth of knowledge about the standards through studying the development of the standards via impressions of the people who developed them. Furthermore, future research could also consider 
the ways in which standards influence the preparation of leaders to address issues related to race and equity.

Despite these limitations, we believe this article contributes to the body of literature that critiques the professional leadership standards for constructing too narrow a definition of what is considered "an essential part of the leadership knowledge base" (Young et al., 2017, p. 250). We find that the leadership standards draw from a nebulous and too narrow conception of justice, which may not fully acknowledge the most pernicious and structural causes of inequality in our American schools. By conceiving of equity-oriented leadership as a wicked problem and recognizing the array of complex issues school leaders face daily, our theoretical orientation leads us to advocate for a set of professional standards that can provide a framework for developing solutions and considering varied approaches to equity and justice. While the standards have evolved since their inception in the late 1990s, our analysis has highlighted that they are still incomplete when it comes to inspiring the kinds of transformative change needed.

\section{References}

Agranoff. R., \& McGuire, M. (1998). Multinetwork management: Collaboration and the hollow state in local economics. Journal of Public Administration Research and Theory, 8(1), 67-91. https://dx.doi.org/10.1093/oxfordjournals.jpart.a024374

Aldeman, C., Hyslop, A., Marchitello, M., Schiess, J. O., \& Pennington, K. (2017, December). An independent review of ESSA state plans: Executive summary. Washington, D.C.: Bellwether Education Partners. Retrieved from https://bellwethereducation.org/

Allen, R. H., \& Sriram, R. D. (2000). The role of standards in innovation. Technological Forecasting and Social Change, 64(2-3), 171-181. https://dx.doi.org/10.1016/S0040-1625(99)00104-3

Billingsley, B., \& McLeskey, J. (2014). What are the roles of principals in inclusive schools? In J. McLeskey, N. L. Waldron, F. Spooner, \& B. Algozzine (Eds.). Handbook of effective inclusive schools: Research and practice (pp. 67-79). New York: Routledge. https://doi.org/10.4324/9780203102930.ch6

Bogotch, I. E. (2002). Educational leadership and social justice: Practice into theory. Journal of School Leadership, 12, 138-156. https://doi.org/10.1177/105268460201200203

Boyce, J., \& Bowers, A. J. (2018). Toward an evolving conceptualization of instructional leadership as leadership for learning: Meta-narrative review of 109 quantitative studies across 25 years. Journal of Educational Administration, 56(2), 161-182. https://doi.org/10.1108/JEA-062016-0064

Brown, V. A., Deane, P. M. Harris, J. A., \& Russell, J. Y. (2010). Towards a just and sustainable future. In V. A. Brown, J. A. Harris, \& J. Y. Russell (Eds.), Tackling wicked problems: Through the transdisciplinary imagination (pp. 3-15). New York, NY: Earthscan. https://doi.org/10.4324/9781849776530

Cambron-McCabe, N., \& McCarthy, M. M. (2005). Educating school leaders for social justice. Educational Policy, 19(1), 201-222. https://doi.org/10.1177/0895904804271609

Childs, C., \& Grooms, A. A. (2018). Improving school attendance through collaboration: A catalyst for community involvement and change. Journal of Education for Students Placed at Risk (JESPAR), 23(1-2), 122-138. https:// doi.org/10.1080/10824669.2018.1439751

Council of Chief State School Officers. (2008). Educational leadership policy standards: ISLLC 2008. Washington, D.C.: Author. Retrieved from http://www.ccsso.org 
Crow, G. M., \& Whiteman, R. S. (2016). Effective preparation program features: A literature review. Journal of Research on Leadership Education, 11(1), 120-148.

https://doi.org/10.1177/1942775116634694

Darling-Hammond, L. (2013). Inequality and school resources: What it will take to close the opportunity gap. In P. L. Carter \& K. G. Welner (Eds.), Closing the opportunity gap: What America must do to give every child an even chance (pp. 77-97). New York, NY: Oxford University Press.

Darling-Hammond, L., Meyerson, D., LaPointe, M. M., \& Orr, M. T. (2010). Preparing principals for a changing world: Lessons from effective school leadership programs. San Francisco, CA: Jossey-Bass. https://doi.org/10.1002/9781118269329

Davis, B. W., Gooden, M. A., \& Micheaux, D. J. (2015). Color-blind leadership: A critical race theory analysis of the ISLLC and ELCC standards. Educational Administration Quarterly, 51(3), 335-371. https://doi.org/10.1177/0013161X15587092

DeMatthews, D. (2015). Making sense of social justice leadership: A case study of a principal's experiences to create a more inclusive school. Leadership and Policy in Schools, 14(2), 139-166. https://doi.org/10.1080/15700763.2014.997939

Derrington, M. L., \& Sharratt, G. (2008). Evaluation of school principals using interstate school leaders licensure consortium (ISLLC) standards. AAS A Journal of Scholarship and Practice, 5(3), 20-29. Retrieved from http://www.aasa.org/

DiPaola, M. F., \& Walther-Thomas, C. (2003). Principals and special education: The critical role of school leaders (COPSSE Document No. IB-7E). Gainesville, FL: University of Florida, Center on Personnel Studies in Special Education. Retrieved from http://www.personnelcenter.org/

Finfgeld-Connett, D. (2014). Use of content analysis to conduct knowledge-building and theorygenerating qualitative systematic reviews. Qualitative Research, 14(3), 341-352. https://doi.org/10.1177/1468794113481790

Fisher-Borne, M., Cain, J. M., \& Martin, S. L. (2015). From mastery to accountability: Cultural humility as an alternative to cultural competence. Social Work Education, 34(2), 165-181. https://doi.org/10.1080/02615479.2014.977244

Furman, G. (2012). Social justice leadership as praxis: Developing capacities through preparation programs. Educational Administration Quarterly, 48(2), 191-229. https://doi.org/10.1177/0013161X11427394

Gibson, C., Smyth, K., Nayowith, G., \& Zaff, J. (2013, September 19). To get the good, you gotta dance with the wicked. Stanford Social Innovation Review. Retrieved from http://www.ssireview.org/

Glenewinkel, J. R. (2011). How do superintendents use the ISLLC Standards to evaluate principals? Or do they? (Unpublished doctoral dissertation). Washington State University, Pullman.

Gooden, M. A. (2012). What does racism have to do with leadership? Countering the idea of colorblind leadership: A reflection on race and the growing pressures of the urban principalship. Educational Foundations, 26(1-2), 67-84.

Gorski, P. (2016). Rethinking the role of "culture" in educational equity: From cultural competence to equity literacy. Multicultural Perspectives, 18(4), 221-226. https://doi.org/10.1080/15210960.2016.1228344

Green, T. L., \& Gooden, M. A. (2014). Transforming out-of-school challenges into opportunities: Community schools reform in the urban Midwest. Urban Education, 49, 930-954. https://doi.org/10.1177/0042085914557643 
Green, T. L. (2015). Leading for urban school reform and community development. Educational Administration Quarterly, 51, 679-711. https://doi.org/10.1177/0013161X15577694

Grissom, J. A., Mitani, H., \& Woo, D. S. (2019). Principal preparation programs and principal outcomes. Educational Administration Quarterly, 55(1), 73-115. https://doi.org/10.1177/0013161X18785865

Grissom, J. A., Blissett, R. S., \& Mitani, H. (2018). Evaluating school principals: Supervisor ratings of principal practice and principal job performance. Educational Evaluation and Policy Analysis, 40(3), 446-472. https://doi.org/10.3102/0162373718783883

Head, B. W., \& Alford, J. (2015). Wicked problems: Implications for public policy and management. Administration \& Society, 47(6), 711-739. https://doi.org/10.1177/0095399713481601

Heck, R. H., \& Hallinger, P. (2005). The study of educational leadership and management: Where does the field stand today? Educational Management Administration \& Leadership, 33(2), 229-244. https://doi.org/10.1177/1741143205051055

Horng, E., \& Loeb, S. (2010). New thinking about instructional leadership. Phi Delta Kappan, 92(3), 66-69. https://doi.org/10.1177/003172171009200319

Hsieh, H. \& Shannon, S. E. (2005, November). Three approaches to qualitative content analysis. Qualitative Health Research, 15(9), 1277-1288. https://doi.org/10.1177/1049732305276687

In Confirmation of Arne Duncan: Hearing of the Committee on Health, Education, Labor, and Pensions, Senate, 111th Cong. 9 (2009) (Testimony of Arne Duncan).

Ishimaru, A. (2013). From heroes to organizers: Principals and education organizing in urban school reform. Educational Administration Quarterly, 49, 3-51. https://doi.org/10.1177/0013161X12448250

Kantor, H., \& Lowe, R. (2013). Educationalizing the welfare state and privatizing education: The evolution of social policy since the New Deal. In P. L. Carter \& K. G. Welner (Eds.), Closing the opportunity gap: What America must do to give every child an even chance (pp. 25-39). New York, NY: Oxford University Press. https://doi.org/10.1093/acprof:oso/9780199982981.003.0003

Khalifa, M. (2012). A "re"-new-“ed" paradigm in successful urban school leadership: Principal as community leader. Educational Administration Quarterly, 48, 424-467. https://doi.org/10.1177/0013161X11432922

Kolko, J. (2012). Wicked problems: Problems worth solving: A bandbook and a call to action. Austin, TX: Austin Center for Design.

Kostyo, S., Cardichon, J., \& Darling-Hammond, L. (2018). Making ESSA's equity promise real: State strategies to close the opportunity gap. Palo Alto, CA: Learning Policy Institute. Retrieved from https:/ / learningpolicyinstitute.org/

Ladson-Billings, G. (2008). A letter to our next president. Journal of Teacher Education, 59(3), 235-239. https://doi.org/10.1177/0022487108317466

Leithwood, K. (1994). Leadership for school restructuring. Educational Administration Quarterly, 30(4), 498-518. https://doi.org/10.1177/0013161X94030004006

Leithwood, K., Harris, A., \& Hopkins, D. (2008). Seven strong claims about successful school leadership. School Leadership and Management, 28(1), 27-42. https://doi.org/10.1080/13632430701800060

Leithwood, K., \& Jantzi, D. (2005). A review of transformational school leadership research 19962005. Leadership and Policy in Schools, 4(3), 177-199. https://doi.org/10.1080/15700760500244769

Leithwood, K. A., \& Riehl, C. (2003). What we know about successful school leadership. Nottingham, UK: National College for School Leadership. 
Maier, M.A. (2018). Content analysis: Advantages and disadvantages. In M. Allen (Ed.) The SAGE encyclopedia of communication research methods (pp. 240-242). Thousand Oaks, CA: SAGE Publications.

Malen, B., Croninger, R., Muncey, D., \& Redmond-Jones, D. (2002). Reconstituting schools: "Testing" the "theory of action". Educational Evaluation and Policy Analysis, 24(2), 113-132. https://doi.org/10.3102/01623737024002113

Maxwell, G. M., Locke, L. A., \& Scheurich, J. J. (2013). Case study of three rural Texas superintendents as equity-oriented change agents. The Qualitative Report, 18(11), 1-23. Retrieved from https://nsuworks.nova.edu/tqr/vol18/iss11/2/

McCarthy, M., Shelton, S. \& Murphy, J. (2016). Policy penetration of the ISLLC standards. Leadership and Policy in Schools, 15(2), 221-230. https://doi.org/10.1080/15700763.2015.1093149

Murphy, J. (2005). Unpacking the foundations of ISLLC standards and addressing concerns in the academic community. Educational Administration Quarterly, 41(1), 154-191. https://doi.org/10.1177/0013161X04269580

Murphy, J. (2017). Professional standards for educational leaders: The empirical, moral, and experiential foundations. Thousand Oaks, CA: Corwin. https://doi.org/10.4135/9781506387079

Murphy, J., Louis, K. S., \& Smylie, M. (2017). Positive school leadership: How the Professional Standards for Educational Leaders can be brought to life. Phi Delta Kappan, 99(1), 21-24. https://doi.org/10.1177/0031721717728273

National Policy Board for Educational Administration. (2011). Educational leadership program recognition standards: Building level. Reston, VA: Author. Retrieved from http://npbea.org/wp-content/uploads/2019/01/ELCC-Building-Level-Standards-2011.pdf

National Policy Board for Educational Administration. (2015). Professional standards for educational leaders 2015. Reston, VA: Author. Retrieved from https://www.wallacefoundation.org/knowledge-center/Documents/ProfessionalStandards-for-Educational-Leaders-2015.pdf

National Policy Board for Educational Administration. (2018a). National Educational Leadership Preparation (NELP) program recognition standards: Building level. Reston, VA: Author. Retrieved from

http:/ / 3fl7112qoj413y6ep2tqpwra.wpengine.netdna-cdn.com/wpcontent/uploads/2018/10/NELP-Building-Standards.pdf

National Policy Board for Educational Administration. (2018b). Preparing for the National Educational Leadership Preparation (NELP) program preview: A companion guide. Reston, VA: Author. Retrieved from http://npbea.org/wp-content/uploads/2018/11/NELP-Companion-Guide.pdf

North, C. E. (2006). More than words? Delving into the substantive meaning(s) of "social justice" in education. Review of Educational Research, 76(4), 507-535. https://doi.org/10.3102/00346543076004507

Owings, W. A., Kaplan, L. S., \& Nunnery, J. (2005). Principal quality, ISLLC standards, and student achievement: A Virginia study. Journal of School Leadership, 15(1), 99-119. https://doi.org/10.1177/105268460501500105

Perilla, N. (2013). Leading the future: Rethinking principal preparation and accountability frameworks. Harvard Journal of Hispanic Policy, 26, 59-68.

Quin, J., Deris, A., Bischoff, G., \& Johnson, J. T. (2015). Comparison of transformational leadership practices: Implications for school districts and principal preparation programs. Journal of Leadership Education, 14(3), 71-85. https://doi.org/10.12806/V14/I3/R5 
Rittel, H. W., \& Webber, M. M. (1973). Dilemmas in general theory of planning. Policy Sciences, 4(2), 155-169. https://doi.org/10.1007/s11077-017-9302-4

Ryan, J. (2012). Struggling for inclusion: Educational leadership in neoliberal times. Greenwich, CT: Information Age.

Ryan, J., \& Higginbottom, K. (2017). Politics, activism and leadership for social justice in education. In D. Waite \& I. Bogotch (Eds.), International handbook of leadership in education (pp. 103-123), Hoboken, NJ: Wiley-Blackwell. https://doi.org/10.1002/9781118956717.ch6

Skrla, L., McKenzie, K. B., \& Scheurich, J. J. (2011). Becoming an equity-oriented change agent. In A. M. Blankstein \& P. D. Houston (Eds.), Leadership for social justice and democracy in our schools (pp. 45-58). Thousand Oaks, CA: Corwin. https://doi.org/10.4135/9781506335278.n3

Smylie, M. A., \& Murphy, J. (2018). School leader standards from ISLLC to PSEL: Notes on their development and the work ahead. UCEA Review, 24. Retrieved from http://npbea.org/

Theoharis, G. (2007). Social justice educational leaders and resistance: Toward a theory of social justice leadership. Educational Administration Quarterly, 43(2), 221-258. https://doi.org/10.1177/0013161X06293717

Theoharis, G. (2009). The school leaders our children deserve: Seven keys to equity, social justice, and school reform. New York, NY: Teachers College Press.

Turnbull, B. J., Anderson, L. M., Riley, D. L., MacFarlane, J. R., \& Aladjem, D. K. (2016). The principal pipeline initiative in action: Building a stronger principalship (vol. 5). Washington, D.C.: Policy Studies Associates, Inc.

Ujifusa, A. (2018, October 7). Betsy DeVos has approved every ESSA plan. Read what's in them. Education Week. Retrieved from https://blogs.edweek.org/

Van Bueren, E. M., Klijn, E., \& Koppenjan, J. F. M. (2003). Dealing with wicked problems in networks: Analyzing an environmental debate from a network perspective. Journal of Public Administration Research and Theory, 13(2), 193-212. https://doi.org/10.1093/jpart/mug017

Weber, R. P. (1990). Basic content analysis (2nd ed.). Beverly Hills, CA: Sage. https://doi.org/10.4135/9781412983488

Weber, E. P., \& Khademian, A. M. (2008). Wicked problems, knowledge challenges, and collaborative capacity builders in network settings. Public Administration Review, 68(2), 334349. https://doi.org/10.1111/j.1540-6210.2007.00866.x

Woodford, R. (2012). School principal evaluation in Wyoming: Alignment between instruments used to evaluate school principals in Wyoming and the ISLLC 2008 Standards for School Leaders (Unpublished doctoral dissertation). University of Wyoming, Laramie.

Young, M. D., Anderson, E., \& Nash, A. M. (2017). Preparing school leaders: Standards-based curriculum in the United States. Leadership and Policy in Schools, 16(2), 228-271. https://doi.org/10.1080/15700763.2017.1298812

Zeichner, K. M. (2009). Teacher education and the struggle for social justice. New York, NY: Routledge. https://doi.org/10.4324/9780203878767 


\title{
About the Authors
}

\section{Amy N. Farley}

University of Cincinnati

amy.farley@uc.edu

ORCID: http://orcid.org/0000-0001-7602-3354

Amy N. Farley is an assistant professor of Educational Leadership \& Policy Studies at the University of Cincinnati. She relies on quantitative and qualitative methods, program evaluation, and policy analysis to explore the impact of policy on students, educators, and educational equity and opportunity. Her substantive research focuses broadly on equity in P-20 education systems and the impact of policies on access and opportunity, including school and university reform, high-stakes data use and measurement, and the disparate impact of policies on certain student and educator populations.

\section{Joshua Childs}

University of Texas at Austin

joshuachilds@austin.utexas.edu

Joshua Childs is an assistant professor of Educational Policy and Planning at the University of Texas at Austin. His research focuses on the role of interorganizational networks and crosssector collaborations to address complex educational issues. Specifically, his work has examined how collaborative approaches involving community organizations and stakeholders can be leveraged to reduce opportunity gaps for students in urban and rural schools.

\section{Olivia A. Johnson}

University of Texas at Austin

Olivia.johnson@utexas.edu

Olivia is a doctoral student in the Education Policy and Planning program at the University of Texas at Austin. Olivia's research focuses on using theories of care as a framework for examining policy implementation in schools of varying socioeconomic opportunity.

\section{About the Guest Editors}

\author{
Augusto Riveros \\ Western University \\ gus.riveros@uwo.ca \\ ORCID: http://orcid.org/0000-0002-9942-6380 \\ Augusto Riveros is associate professor in critical policy equity and leadership studies in the \\ Faculty of Education at Western University in Ontario. Canada. His areas of interest include \\ methods and theory in educational administration and leadership, policy analysis and education \\ reform. His work has been published in numerous international journals and edited books. Dr. \\ Riveros' research has been supported by the Social Sciences and Humanities Research Council \\ of Canada (SSHRC).
}

\section{Wei Wei}

Western University

wwei32@uwo.ca 
ORCID: http://orcid.org/0000-0002-0090-5614

Wei Wei is a Ph.D. Candidate in critical policy, equity, and leadership studies in the Faculty of Education at Western University in Ontario Canada. Her research interests include educational leadership, policy analysis, and comparative and international education.

\section{Special Issue \\ Standards and Competency Frameworks for School Administrators: Global, Comparative and Critical Perspectives \\ education policy analysis archives}

Volume 27 Number $115 \quad$ September 23, 2019

ISSN 1068-2341

\section{(c) (1) (-)}

EY SA Readers are free to copy, display, distribute, and adapt this article, as long as the work is attributed to the author(s) and Education Policy Analysis Archives, the changes are identified, and the same license applies to the derivative work. More details of this Creative Commons license are available at https://creativecommons.org/licenses/by-sa/2.0/. EPAA is published by the Mary Lou Fulton Institute and Graduate School of Education at Arizona State University Articles are indexed in CIRC (Clasificación Integrada de Revistas Científicas, Spain), DIALNET (Spain), Directory of Open Access Journals, EBSCO Education Research Complete, ERIC, Education Full Text (H.W. Wilson), QUALIS A1 (Brazil), SCImago Journal Rank, SCOPUS, SOCOLAR (China).

Please send errata notes to Audrey Amrein-Beardsley at audrey.beardsley@asu.edu

Join EPAA's Facebook community at https://www.facebook.com/EPAAAAPE and Twitter feed@epaa_aape. 


\section{education policy analysis archives editorial board}

Lead Editor: Audrey Amrein-Beardsley (Arizona State University)

Editor Consultor: Gustavo E. Fischman (Arizona State University)

Associate Editors: Melanie Bertrand, David Carlson, Lauren Harris, Eugene Judson, Mirka Koro-Ljungberg, Daniel Liou, Scott Marley, Molly Ott, Iveta Silova (Arizona State University)

\section{Cristina Alfaro}

San Diego State University

Gary Anderson

New York University

Michael W. Apple

University of Wisconsin, Madison

\section{Jeff Bale}

University of Toronto, Canada

Aaron Bevanot SUNY Albany

David C. Berliner

Arizona State University

Henry Braun Boston College

Casey Cobb
University of Connecticut
Arnold Danzig
San Jose State University
Linda Darling-Hammond
Stanford University
Elizabeth H. DeBray
University of Georgia
David E. DeMatthews
University of Texas at Austin
Chad d'Entremont Rennie Center
for Education Research \& Policy
John Diamond
University of Wisconsin, Madison
Matthew Di Carlo
Albert Shanker Institute
Sherman Dorn
Arizona State University
Michael J. Dumas
University of California, Berkeley
Kathy Escamilla
University ofColorado, Boulder
Yariv Feniger Ben-Gurion
University of the Negev
Melissa Lynn Freeman
Adams State College
Rachael Gabriel
University of Connecticut

Amy Garrett Dikkers University

of North Carolina, Wilmington

Gene V Glass

Arizona State University

Ronald Glass University of

California, Santa Cruz

Jacob P. K. Gross

University of Louisville

Eric M. Haas WestEd

Julian Vasquez Heilig California

State University, Sacramento

Kimberly Kappler Hewitt

University of North Carolina

Greensboro

Aimee Howley Ohio University

Steve Klees University of Maryland

Jaekyung Lee SUNY Buffalo

Jessica Nina Lester

Indiana University

Amanda E. Lewis University of

Illinois, Chicago

Chad R. Lochmiller Indiana

University

Christopher Lubienski Indiana

University

Sarah Lubienski Indiana University

William J. Mathis

University of Colorado, Boulder

Michele S. Moses

University of Colorado, Boulder

Julianne Moss

Deakin University, Australia

Sharon Nichols

University of Texas, San Antonio

Eric Parsons

University of Missouri-Columbia

Amanda U. Potterton

University of Kentucky

Susan L. Robertson

Bristol University
Gloria M. Rodriguez

University of California, Davis

R. Anthony Rolle

University of Houston

A. G. Rud

Washington State University

Patricia Sánchez University of

University of Texas, San Antonio

Janelle Scott University of

California, Berkeley

Jack Schneider University of

Massachusetts Lowell

Noah Sobe Loyola University

Nelly P. Stromquist

University of Maryland

Benjamin Superfine

University of Illinois, Chicago

Adai Tefera

Virginia Commonwealth University

A. Chris Torres

Michigan State University

Tina Trujillo

University of California, Berkeley

Federico R. Waitoller

University of Illinois, Chicago

Larisa Warhol

University of Connecticut

John Weathers University of

Colorado, Colorado Springs

Kevin Welner

University of Colorado, Boulder

Terrence G. Wiley

Center for Applied Linguistics

John Willinsky

Stanford University

Jennifer R. Wolgemuth

University of South Florida

Kyo Yamashiro

Claremont Graduate University

Miri Yemini

Tel Aviv University, Israel 


\section{archivos analíticos de políticas educativas consejo editorial}

Editor Consultor: Gustavo E. Fischman (Arizona State University)

Editores Asociados: Felicitas Acosta (Universidad Nacional de General Sarmiento, Argentina), Armando Alcántara Santuario (Universidad Nacional Autónoma de México), Ignacio Barrenechea, Jason Beech (Universidad de San Andrés), Angelica Buendia, (Metropolitan Autonomous University), Alejandra Falabella (Universidad Alberto Hurtado, Chile), Veronica Gottau (Universidad Torcuato Di Tella), Antonio Luzon, (Universidad de Granada), José Luis Ramírez, (Universidad de Sonora), Paula Razquin, Axel Rivas (Universidad de San Andrés), Maria Alejandra Tejada-Gómez (Pontificia Universidad Javeriana, Colombia)

\section{Claudio Almonacid}

Universidad Metropolitana de

Ciencias de la Educación, Chile

\section{Miguel Ángel Arias Ortega}

Universidad Autónoma de la

Ciudad de México

Xavier Besalú Costa

Universitat de Girona, España

Xavier Bonal Sarro Universidad

Autónoma de Barcelona, España

Antonio Bolívar Boitia

Universidad de Granada, España

José Joaquín Brunner Universidad

Diego Portales, Chile

Damián Canales Sánchez

Instituto Nacional para la

Evaluación de la Educación,

México

Gabriela de la Cruz Flores

Universidad Nacional Autónoma de

México

Marco Antonio Delgado Fuentes

Universidad Iberoamericana,

México

Inés Dussel, DIE-CINVESTAV, México

Pedro Flores Crespo Universidad Iberoamericana, México
Ana María García de Fanelli

Centro de Estudios de Estado y

Sociedad (CEDES) CONICET,

Argentina

Juan Carlos González Faraco

Universidad de Huelva, España

María Clemente Linuesa

Universidad de Salamanca, España

Jaume Martínez Bonafé

Universitat de València, España

Alejandro Márquez Jiménez

Instituto de Investigaciones sobre la Universidad y la Educación,

UNAM, México

María Guadalupe Olivier Tellez, Universidad Pedagógica Nacional, México

Miguel Pereyra Universidad de

Granada, España

Mónica Pini Universidad Nacional

de San Martín, Argentina

Omar Orlando Pulido Chaves

Instituto para la Investigación

Educativa y el Desarrollo

Pedagógico (IDEP)

José Ignacio Rivas Flores

Universidad de Málaga, España
Miriam Rodríguez Vargas

Universidad Autónoma de

Tamaulipas, México

José Gregorio Rodríguez

Universidad Nacional de Colombia, Colombia

Mario Rueda Beltrán Instituto de

Investigaciones sobre la Universidad y la Educación, UNAM, México

José Luis San Fabián Maroto

Universidad de Oviedo, España

Jurjo Torres Santomé, Universidad de la Coruña, España

Yengny Marisol Silva Laya

Universidad Iberoamericana, México

Ernesto Treviño Ronzón

Universidad Veracruzana, México

Ernesto Treviño Villarreal

Universidad Diego Portales

Santiago, Chile

Antoni Verger Planells

Universidad Autónoma de

Barcelona, España

Catalina Wainerman

Universidad de San Andrés,

Argentina

Juan Carlos Yáñez Velazco

Universidad de Colima, México 


\section{arquivos analíticos de políticas educativas conselho editorial}

Editor Consultor: Gustavo E. Fischman (Arizona State University)

Editoras Associadas: Kaizo Iwakami Beltrao, (Brazilian School of Public and Private Management - EBAPE/FGV, Brazil), Geovana Mendonça Lunardi Mendes (Universidade do Estado de Santa Catarina), Gilberto José Miranda, (Universidade Federal de Uberlândia, Brazil), Marcia Pletsch, Sandra Regina Sales (Universidade Federal Rural do Rio de Janeiro)

\author{
Almerindo Afonso \\ Universidade do Minho \\ Portugal

\section{Rosanna Maria Barros Sá \\ Universidade do Algarve} \\ Portugal \\ Maria Helena Bonilla \\ Universidade Federal da Bahia \\ Brasil \\ Rosa Maria Bueno Fischer \\ Universidade Federal do Rio Grande \\ do Sul, Brasil

\section{Alice Casimiro Lopes \\ Universidade do Estado do Rio de \\ Janeiro, Brasil}

\section{Suzana Feldens Schwertner \\ Centro Universitário Univates \\ Brasil}

Flávia Miller Naethe Motta

Universidade Federal Rural do Rio de Janeiro, Brasil

\section{Alexandre Fernandez Vaz \\ Universidade Federal de Santa \\ Catarina, Brasil}

\section{Regina Célia Linhares Hostins \\ Universidade do Vale do Itajaí, Brasil}

Alfredo Macedo Gomes
Universidade Federal de Pernambuco
Brasil

Jefferson Mainardes

Universidade Estadual de Ponta

Grossa, Brasil

\section{Jader Janer Moreira Lopes \\ Universidade Federal Fluminense e \\ Universidade Federal de Juiz de Fora, Brasil \\ Debora Nunes \\ Universidade Federal do Rio Grande do Norte, Brasil}

\section{Alda Junqueira Marin \\ Pontifícia Universidade Católica de São Paulo, Brasil}

\section{Dalila Andrade Oliveira}

Universidade Federal de Minas

Gerais, Brasil
José Augusto Pacheco

Universidade do Minho, Portugal

Jane Paiva

Universidade do Estado do Rio de

Janeiro, Brasil

Paulo Alberto Santos Vieira

Universidade do Estado de Mato

Grosso, Brasil

Fabiany de Cássia Tavares Silva

Universidade Federal do Mato

Grosso do Sul, Brasil

\section{António Teodoro}

Universidade Lusófona

Portugal

\section{Lílian do Valle}

Universidade do Estado do Rio de Janeiro, Brasil

\section{Alfredo Veiga-Neto}

Universidade Federal do Rio Grande do Sul, Brasil 